\title{
Penetration of sparfloxacin and ciprofloxacin into alveolar macrophages, epithelial lining fluid, and polymorphonuclear leucocytes
}

\author{
P. Schüler*, K. Zemper*, K. Borner**, P. Koeppe+, T. Schaberg*, H. Lode*
}

Penetration of sparfloxacin and ciprofloxacin into alveolar macrophages, epithelial lining fluid, and polymorphonuclear leucocytes. P. Schüler, K. Zemper, K. Borner, P. Koeppe, T. Schaberg, H. Lode. (CERS Journals Ltd 1997.

ABSTRACT: Sparfloxacin (SPX), a novel fluoroquinolone with a broad spectrum of antibacterial activity, has been shown, in vitro, to be more effective against common pulmonary pathogens, particularly Streptococcus pneumoniae, Mycoplasma pneumoniae and some intracellular organisms, than ciprofloxacin (CPX).

The objective of this open, comparative, randomized study in two parallel groups was to assess the serum concentrations and penetration of SPX and CPX into alveolar macrophages (AMs), epithelial lining fluid (ELF), and peripheral polymorphonuclear leucocytes (PMNs). Patients received either a single oral dose of SPX, $400 \mathrm{mg}$ (16 patients), or CPX, $500 \mathrm{mg}$ (15 patients), at various times before a routine diagnostic bronchoscopy was performed. Antibiotic concentrations were determined by using a microbiological assay.

The median serum elimination half-lives were $17.3 \mathrm{~h}$ for SPX and $5.3 \mathrm{~h}$ for CPX. Peak levels (median $\pm 68 \%$ confidence range) of CPX were attained in AMs (7.6 \pm 1.7 $\left.\mathrm{mg} \cdot \mathrm{L}^{-1}\right)$ at $5 \mathrm{~h}$ after admission, and in both ELF $\left(2.13 \pm 0.91 \mathrm{mg} \cdot \mathrm{L}^{-1}\right)$ and PMNs $\left(9.1 \pm 6.2 \mathrm{mg} \cdot \mathrm{L}^{-1}\right)$ at $2.5 \mathrm{~h}$ after administration. SPX achieved comparable peak levels in PMNs (median $\pm 68 \%$ range, $9.4 \pm 1.1 \mathrm{mg} \cdot \mathrm{L}^{-1}$ at $5 \mathrm{~h}$ ), but peak concentrations attained in AMs and ELF $\left(35.1 \pm 15.4\right.$ and $32.2 \pm 28.2 \mathrm{mg} \cdot \mathrm{L}^{-1}$, respectively, at $\left.24 \mathrm{~h}\right)$ were several times higher than those of CPX. SPX demonstrated substantially greater accumulation in all three sites than did CPX (peak site to serum ratios of 11.0 $\pm 4.3,65.5 \pm 28.4$ and $63.0 \pm 66$ versus $4.94 \pm 0.64,10.6 \pm 3.7$ and 10.6 \pm 3.7 for PMNs, AMs and ELF, respectively).

The results indicate, that sparfloxacin has a long elimination half-life and that it achieves higher concentrations in alveolar macrophages and epithelial lining fluid than ciprofloxacin. Site concentrations of sparfloxacin greatly exceeded the minimal inhibitory concentrations of common respiratory pathogens.

Eur Respir J 1997; 10: 1130-1136.

Widely-used fluoroquinolones, such as ciprofloxacin and ofloxacin, exhibit a broad antimicrobial spectrum, with good in vitro activity against Gram-negative bacteria. However, they are less potent against some common respiratory pathogens, particularly Streptococcus pneumoniae, Mycoplasma pneumoniae and some intracellular organisms. Sparfloxacin is a novel quinolone derivative with comparable activity to ciprofloxacin and ofloxacin against gram-negative organisms, but it possesses greater activity than these quinolones against Gram-positive cocci (including S. pneumoniae), Mycoplasma spp., Chlamydia spp., Mycobacteria spp., and some anaerobes [1-10]. The pharmacokinetics of sparfloxacin are characterized by: good absorption after oral administration; good penetration into many tissues and body fluids; and a long plasma elimination half-life, ranging 16-24 h [11-14].

Epithelial lining fluid (ELF) has been considered to be an important site of infection in pneumonia, and both the alveolar macrophages (AMs) and the polymorphonuclear leucocytes (PMNs) represent important sites of intracellular infection [15]. The capability of intracel-
*Dept of Pneumology I, Hospital Heckeshorn, **Institute of Clinical Chemistry and +Dept of Medical Physics, Hospital Benjamin Franklin of Freie Universität, Berlin, Germany.

\section{Correspondence: H. Lode}

Dept of Pneumology I and Infectious Diseases

hospital Heckeshorn

Zum Heckeshorn 33

14109 Berlin

Germany

\section{Keywords: Alveolar macrophages} ciprofloxacin

epithelial lining fluid

peripheral polymorphonuclear leucocytes sparfloxacin

Received: August 121996

Accepted after revision December 111996

This study was supported by a joint grant from Rhône D.P.C. Europe, Antony, France and Rhône Poulenc Rorer GmbH, Cologne, Germany. lular pathogens to penetrate and multiply in phagocytes plays an important role in the dissemination of the infectious process, since phagocytes can quickly pass vascular and nonvascular epithelial membranes. Hence, it follows that sufficient drug accumulation in phagocytes is needed to achieve activity against intracellular pathogens [16].

Fluoroquinolones, including sparfloxacin, have been shown to achieve high intracellular concentrations. The objective of this comparative study was to evaluate the penetration of sparfloxacin and ciprofloxacin into ELF, AMs, and PMN following administration of a single standard oral dose.

Materials and methods

\section{Study design and subjects}

This was an open, comparative, randomized clinical study in two parallel groups. A total of 31 patients (23 
males and 8 females; 26 smokers and 5 nonsmokers; age mean \pm sD $60 \pm 10$ yrs; body weight $75 \pm 16 \mathrm{~kg}$; serum creatinine $79.4 \pm 16.0 \mu \mathrm{mol} \cdot \mathrm{L}^{-1}$ ) undergoing diagnostic fibreoptic bronchoscopy, in most cases for suspicion of lung cancer, were enrolled. All patients gave their written informed consent, and the protocol of the study was approved by the Ethics Committee of the Hospital Benjamin Franklin, Freie Universität, Berlin, Germany. Noninclusion criteria were: child-bearing potential; pregnancy; lactation; an existing lung infection; a severely immunocompromised status; a haemodynamically unstable condition; the use of any antibacterial agent before study entry; a concomitant disease that may interfere with the course of the study; human immunodeficiency virus (HIV) infection; renal insufficiency (creatinine >200 $\left.\mu \mathrm{mol} \cdot \mathrm{L}^{-1}\right)$, severe psychiatric disease; drug or alcohol abuse; significantly abnormal results on laboratory testing, allergy to quinolones; cardiac frequency $<40$ beats. $\mathrm{min}^{-1}$; congenital prolonged QT syndrome; and concomitant therapy with either an antacid, iron salts, theophylline, anticoagulants, antipsychotics, anticonvulsants, antiarrhythmics or a medication known to cause QT prolongation. A complete physical examination and a common laboratory profile were performed before and at the end of the study.

All study subjects were divided into two groups: Group A (16 patients) were administered a single dose of 400 mg sparfloxacin; and Group B (15 patients) were administered a single dose of $500 \mathrm{mg}$ ciprofloxacin.

Both groups were divided into three subgroups, which took the fluoroquinolones in accordance to a dose schedule: Subgroups A1 and B1 (5 patients per group) took their medication $2.5 \mathrm{~h}$ before bronchoscopy; Subgroups A2 and B2 (6 and 5 patients, respectively) $5 \mathrm{~h}$ before bronchoscopy; and Subgroups A3 and B3 (5 patients per group) took their dose 24 and $12 \mathrm{~h}$ before bronchoscopy, respectively. An interval of $12 \mathrm{~h}$ between Subgroups A3 (sparfloxacin) and B3 (ciprofloxacin) was set, because it had been decided to monitor the levels of each drug throughout their recommended dosing intervals, i.e. SPX for $24 \mathrm{~h}$, and CPX for $12 \mathrm{~h}$.

\section{Bronchoalveolar lavage (BAL) and sample processing}

Fibreoptic bronchoscopy (FBF 5; Olympus, Japan) was performed using a standard premedication consisting of $10-15 \mathrm{mg}$ of nebulized $4 \%$ xylocaine, $0.5 \mathrm{mg}$ atropine, $10-15 \mathrm{mg}$ hydrocodone, and $1-1.5 \mathrm{mg}$ midazolone, administered intramuscularly $20 \mathrm{~min}$ prior to bronchoscopy. The BAL was mainly performed in the lingula, or in the middle lobe if the lingula was suspect for malignancy. A conventional BAL using a volume of $160 \mathrm{~mL}$ of $0.9 \%$ saline (lavage divided into four aliquots) was performed. Gentle aspiration was performed following each of the four $40 \mathrm{~mL}$ aliquots. The aspirate of the first $40 \mathrm{~mL}$ was discarded to avoid any contamination of the sample with proximal airway cells and fluid [17]. The aspirates of the remaining three aliquots were pooled. The lavage fluid was filtered through a sterile gauze, and then centrifuged at $4{ }^{\circ} \mathrm{C}$ and 500 $\times \mathrm{g}$ for $10 \mathrm{~min}$. Five to 10 millilitres of the supernatant were used to determine the antibiotic concentrations in a microbiological assay. The remaining volume of the supernatant was used to determine the concentration of urea. All samples were stored frozen at $-80^{\circ} \mathrm{C}$, protected from light until assayed.

\section{Preparation of AMs}

The cell pellet remaining after centrifugation of the BAL fluid resuspended twice, washed and centrifuged in buffer (Hank's balanced salt solution (HBSS)), and counted with a haemocytometer. The viability of AMs was proved by $0.1 \%$ trypan blue (Sigma Chemicals, Diesenhofen, Germany) dye exclusion, and the macrophage population was visualized by nonspecific esterase (Sigma Chemicals) staining, to ensure that a uniform macrophage population was obtained [18]. The proportion of AMs was always greater than $90 \%$. Cells were then resuspended in distilled water to obtain a concentration of $1 \times 10^{6}$ cells $\cdot 200 \mu \mathrm{L}$. The suspension of $1 \times 10^{6}$ macrophages was then ultrasonicated on ice for $1 \mathrm{~min}$ before measurement of antibiotic concentrations. All samples were stored at $-30^{\circ} \mathrm{C}$, protected from light.

\section{Blood samples}

Blood samples were taken prior to drug administration, $1 \mathrm{~h}$ before bronchoscopy, during bronchoscopy, and $1 \mathrm{~h}$ after bronchoscopy. Blood samples were allowed to clot at room temperature for $15 \mathrm{~min}$, and then centrifuged at 3,000 rpm using a refrigerating centrifuge. Serum was then aspirated and divided into two aliquots to determine the concentrations of urea and antibiotic. All samples were stored frozen at $-30^{\circ} \mathrm{C}$, protected from light until assayed.

\section{Preparation of PMN}

Approximately $20 \mathrm{~mL}$ of venous blood obtained using a heparinized syringe (final concentration of heparin $500 \mathrm{IE}$ ) were placed in a $50 \mathrm{~mL}$ conical tube (Falcon; Becton Dickinson, NJ, USA) and then gently mixed with $10 \mathrm{~mL}$ of $1 \%$ dextran 40 (Onkovertin N; Braun, Melsungen, Germany). The tube was then incubated with $5 \% \mathrm{CO}_{2}$ at $37^{\circ} \mathrm{C}$ for $60 \mathrm{~min}$. The supernatant containing the white blood cells was carefully transferred to a new conical tube and underlayed with Ficoll (Seromed Biochrome KG, Berlin, Germany), density 1,077. After centrifugation $\left(45 \mathrm{~min}\right.$ at $\left.400 \times \mathrm{g}, 20^{\circ} \mathrm{C}\right)$, the supernatant containing lymphocytes and monocytes was discarded and the pellet consisting of the PMNs and residual red blood cells was saved. Erythrocytes were destroyed by hypotonic lysis with $0.2 \%$ saline. After centrifugation, the supernatant was discarded and the PMNs were resuspended in buffer (HBSS without $\mathrm{Ca}^{2+}$ and $\mathrm{Mg}^{2+}$ ) and again centrifuged. The viability of the PMNs was proved by dye exclusion, after staining the cells with $0.1 \%$ trypan blue (Sigma Chemicals, Poole, UK) [19]; and the cells were then counted using a haemocytometer. Thereafter, the cells were resuspended in distilled water and adjusted to a concentration of $2 \times 10^{7}$ cells. $200 \mu \mathrm{L}^{-1}$. The PMNs were then ultrasonicated on ice for $1 \mathrm{~min}$ and the antibiotic concentration was measured. All samples were stored frozen at $-30^{\circ} \mathrm{C}$, protected from light until assayed. 


\section{Buffers, media and antibiotic standards}

Modified HBSS, final $\mathrm{pH} 7.3-7.4$, containing: $\mathrm{NaCl}$ $8.0 \mathrm{~g} \cdot \mathrm{L}^{-1}, \mathrm{KCl} 0.4 \mathrm{~g} \cdot \mathrm{L}^{-1}, \mathrm{NaHPO}_{4} 0.04788 \mathrm{~g} \cdot \mathrm{L}^{-1}, \mathrm{~K}_{2} \mathrm{HPO}_{4}$ $0.06 \mathrm{~g} \cdot \mathrm{L}^{-1}$, and glucose $1.0 \mathrm{~g} \cdot \mathrm{L}^{-1}$ (Sigma Chemicals, Poole, UK) was used as buffer for preparation of the AMs. The medium used for the microbiological assays was $\mathrm{N}$-agar, containing: $\mathrm{Na}_{2} \mathrm{HPO}_{4} 2.0 \mathrm{~g} \cdot \mathrm{L}^{-1}, \mathrm{NaCl} 3.0 \mathrm{~g} \cdot \mathrm{L}^{-1}$, neutralpepton $10.0 \mathrm{~g} \cdot \mathrm{L}^{-1}$ (Oxoid, Wesel, Germany), lablemka $10.0 \mathrm{~g} \cdot \mathrm{L}^{-1}$ (Oxoid), Bacto agar $15.0 \mathrm{~g} \cdot \mathrm{L}^{-1}$ (Difco, Augsburg, Germany), and 1.0\% dextrose, final $\mathrm{pH}$ 7.3-7.4. Sörensen buffer, consisting of a mixture of $400 \mathrm{~mL}$ of solution I $\left(9.078 \mathrm{~g} \mathrm{KH}_{2} \mathrm{PO}_{4}\right.$ in $\left.1.0 \mathrm{~L} \mathrm{H}_{2} \mathrm{O}\right)$ and $600 \mathrm{~mL}$ of solution II (11.876 $\mathrm{g} \mathrm{Na}_{2} \mathrm{HPO}_{4} \times 2 \mathrm{H}_{2} \mathrm{O}$ in $\left.1.0 \mathrm{~L} \mathrm{H}_{2} \mathrm{O}\right)$, final $\mathrm{pH} 7.0$, was used for the antibiotic standards. The buffer was sterilized and then stored at $4^{\circ} \mathrm{C}$. Pooled serum used for the antibiotic standards was provided by the blood donor service (DRK Blutspendedienst, Berlin) of the Hospital Benjamin Franklin, Freie Universität, Berlin.

Sparfloxacin and ciprofloxacin in powder form were provided by Rhône-Poulenc Rorer GmbH, Köln, Germany and Bayer AG, Wuppertal, Germany, respectively. Dilutions of the compounds were made on the day of use, according to the instructions of the manufacturers.

\section{Microbiological assay}

Concentrations of sparfloxacin and ciprofloxacin were determined microbiologically, using the agar diffusion method described by REEves and Bywater [20], with $\mathrm{N}$-agar as growth medium. Bacillus subtilis American Type Culture Collection (ATCC) 6633 and Klebsiella pneumoniae ATCC 10031 were used as indicator organisms for sparfloxacin and ciprofloxacin, respectively. Prior to the assay, it was checked that the antibioticfree samples had no inhibitory effect on the test organisms. After suitable dilution, the samples were incubated either at $30^{\circ} \mathrm{C}$ (K. pneumoniae) or $37^{\circ} \mathrm{C}$ (B. subtilis) for $18 \mathrm{~h}$. The lower limits of sensitivity of the assays were $0.03 \mathrm{mg} \cdot \mathrm{L}^{-1}$ for sparfloxacin and $0.015 \mathrm{mg} \cdot \mathrm{mL}^{-1}$ for ciprofloxacin, respectively. The assay precision, as determined by the coefficient of variation (CV) for control samples with antibiotic concentrations ranging $0.5-2$ $\mathrm{mg} \cdot \mathrm{L}^{-1}$ were as follows: sparfloxacin-buffer $4.1-6.5 \%$; sparfloxacin-serum 4.0-8.4\%; ciprofloxacin-buffer 3.2$6.4 \%$; and ciprofloxacin-senum $3.7-4.6 \%$.

\section{Calculation of the antibiotic concentration in the ELF}

The concentration of urea in BAL was determined to quantify the volume of ELF [21]. After vacuum-concentration of BAL, the concentration of urea was determined using a modified Sigma Diagnostic Kit UV-66 (Sigma Chemicals, Poole, UK). The antibiotic concentrations in ELF were determined as follows [22]:

ELF volume $=\quad \frac{\text { [urea] lavage } \times \text { volume lavage }}{\text { [urea] serum }}$
[urea] ELF $=\quad \frac{\text { [urea] lavage } \times \text { volume lavage }}{\text { volume ELF }}$

[antibiotics] ELF $=$ [urea] ELF $\times$ [antibiotics] lavage [urea] lavage

Calculation of antibiotic concentrations in AMs and PMNs

Intracellular concentrations of antibiotics were determined according to the following formulae:

$$
\mathrm{c}(\mathrm{I})=\mathrm{f} \times \mathrm{c}(\mathrm{L})=33.57 \times \mathrm{c}(\mathrm{L})
$$

mean cell volume: $V$ cell $=\ldots \mathrm{fL}$; total number of cells: $\mathrm{Z}=$ $2 \times 10^{7}$ PMNs, $\mathrm{Z}=1 \times 10^{6} \mathrm{AMs}$; total cell volume: $V=\mathrm{Z} \times$ $V$ cell; suspension fluid (aq dest): $V(\mathrm{~L})=200 \mu \mathrm{L}$; suspension volume: $V(\mathrm{~L})+V$; factor of dilution: $\mathrm{f}=[V(\mathrm{~L})+V] / V$; measured concentration in suspension: $\mathrm{c}(\mathrm{L})$; measured serum concentration: $c(E)$; accumulation factor: $A=c(I) /$ $\mathrm{c}(\mathrm{E})$, supposing that the mean cell volumes of PMNs and AMs are $307 \mathrm{fL}$ [23] and 2,653 fI (data from our own experiments), respectively.

\section{Pharmacokinetic and statistical analysis}

The serum data were studied according to an open one compartment model (a) as well as noncompartmentally (b).

(a) The decision for this model was based on the criterion of Schwarz [24]. The results of the model approach are used to calculate the lag time ( $t \mathrm{lag})$, the maximum concentration $(\mathrm{Cmax})$, the time to maximum concentration $(t \max )$, the absorption rate constant $(\mathrm{ka})$ and the elimination rate constant (kel).

(b) The serum area under the curve (AUC) was calculated as "area under the data" (AUD) by the linear trapezoidal rule, from time zero until time of the last measurement ( $t$ last). The total area is approximated by: AUDtot $=$ AUD $+C(t$ last $) / \mathrm{kcl}$. The volume of distribution as well as the (total) clearance values were calculated from AUDtot, i.e. noncompartmentally. The final values are expressed as median \pm standard range $(=68 \%$ confidence range $)$ of the individual results.

The parameters directly depending on the dose were recalculated for dose per either $70 \mathrm{~kg}$ of body weight (Cmax, AUDtot, volume of distribution/unknown bioavailability $(V \mathrm{ss} / \mathrm{F}))$ or $1.73 \mathrm{~m}^{2}$ of body surface (oral clearance/unknown bioavailability (CL/F)) [25, 26]. Due to lack of data during the absorption phase, it was not possible to determine the $\mathrm{Cmax}$ and $t$ max of ciprofloxacin.

For analysis of multiple comparisons between the concentrations of the two quinolones, the test of WILCOXON and WiLcox [27] was used. A p-value equal to or less than 0.05 was considered significant, and a p-value equal to or less than was considered highly significant.

\section{Results}

\section{Pharmacokinetic parameters}

Serum concentration-time curves and pharmacokinetic parameters of sparfloxacin and ciprofloxacin are depicted in figure $1 \mathrm{a}$ and $\mathrm{b}$. 


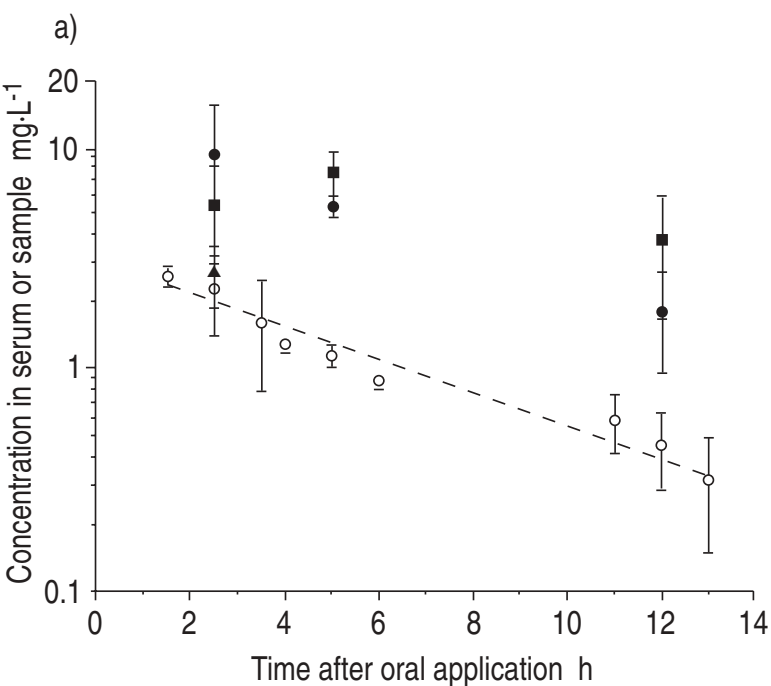

b)

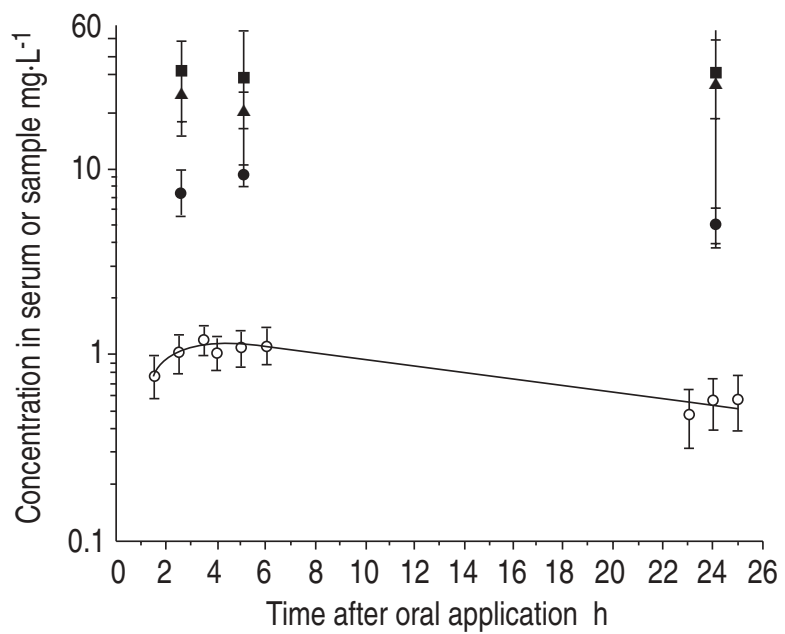

Fig. 1. - Median ( $\pm 68 \%$ confidence range) concentrations of a single oral dose of a) ciprofloxacin, $500 \mathrm{mg}(\mathrm{n}=15)$ and $\mathrm{b})$ sparfloxacin, $400 \mathrm{mg}(\mathrm{n}=16)$, in serum, peripheral granulocytes (PMNs), alveolar macrophages (AMs) and epithelial lining fluid (ELF). Concentrations were determined by bioassay. For ciprofloxacin (a), the concentrations of ELF were only detectable $2.5 \mathrm{~h}$ after dosage. $\_$: serum regression function; O : serum; • : PMNs; $\square$ : AMs; $\mathbf{\Delta}$ : ELF.

Ciprofloxacin (median $\pm 68 \%$ confidence range) serum concentrations determined at the time of the first blood sample (at $1.5 \mathrm{~h}$ ) and at the end of the recommended dosing interval (at $12 \mathrm{~h}$ ) were $2.68 \pm 0.34$ and $0.43 \pm 0.23$ $\mathrm{mg} \cdot \mathrm{L}^{-1}$. The values obtained for the total area under the concentration-time curve (AUCtot) and the elimination half-life were $17.7 \mathrm{mg} \cdot \mathrm{L}^{-1} \times \mathrm{h}$ and $5.3 \mathrm{~h}$, respectively.

The highest serum concentrations of sparfloxacin were achieved at $6 \mathrm{~h}\left(1.10 \pm 0.37 \mathrm{mg} \cdot \mathrm{L}^{-1}\right)$ (fig. $\left.1 \mathrm{~b}\right)$. Concentrations at the end of recommended dosing interval (at $24 \mathrm{~h}$ ) were $0.49 \pm 0.22 \mathrm{mg} \cdot \mathrm{L}^{-1}$. The values obtained for the area under the concentration-time-curve (AUCtot) and the elimination half-life at the $\beta$-phase were 35.5 $\mathrm{mg} \cdot \mathrm{L}^{-1} \times \mathrm{h}$ and $17.3 \mathrm{~h}$, respectively.

\section{Intracellular concentrations}

Values (median $\pm 68 \%$ confidence range) of intracellular concentrations determined $2.5,5$ and $12 \mathrm{~h}$ after

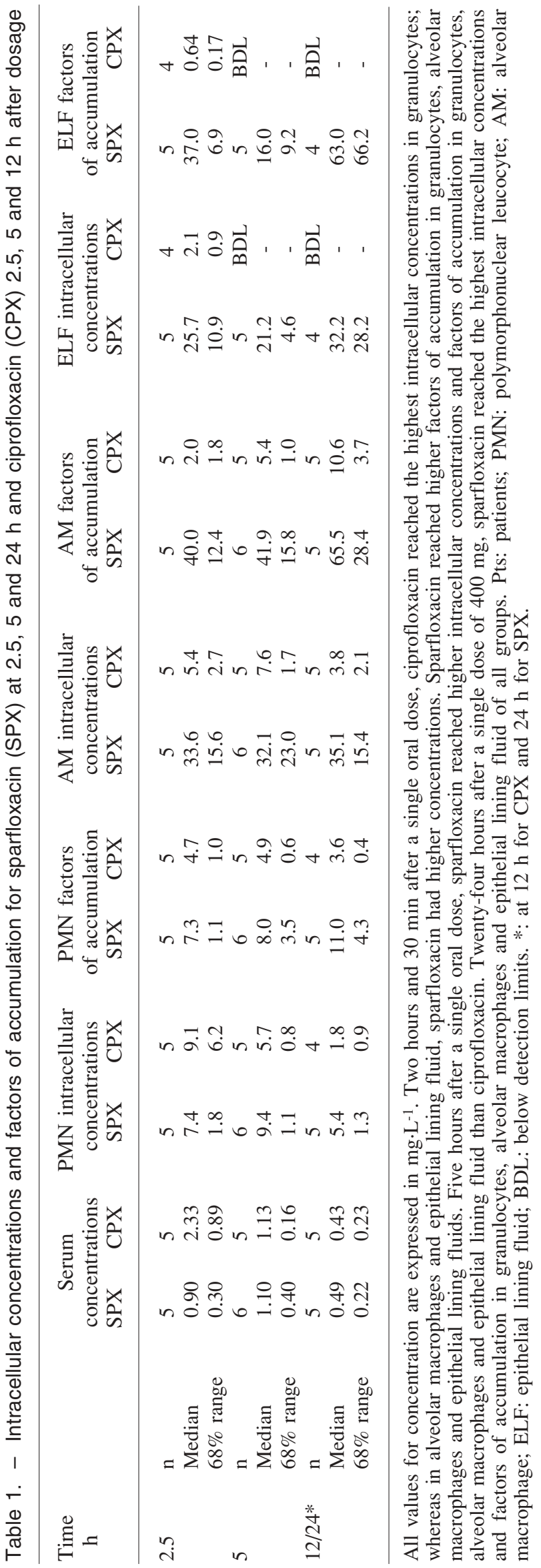


ciprofloxacin and 2.5, 5 and $24 \mathrm{~h}$ after sparfloxacin administration are depicted in figure $1 \mathrm{a}$ and $\mathrm{b}$ and table 1 .

The intracellular peak concentrations of ciprofloxacin and sparfloxacin in PMNs were 9.1 \pm 6.2 and 9.4 \pm 1.1 $\mathrm{mg} \cdot \mathrm{L}^{-1}$, respectively (difference not statistically significant). However, the maximum concentrations of sparfloxacin in AMs were five times higher than those of ciprofloxacin $\left(35.1 \pm 28.2\right.$ vs $7.6 \pm 1.7 \mathrm{mg} \cdot \mathrm{L}^{-1}$; $\left.\mathrm{p} \leq 0.01\right)$. Sparfloxacin also displayed significantly greater penetration into $\mathrm{ELF}\left(32.2 \pm 28.2\right.$ s $2.13 \pm 0.91 \mathrm{mg} \cdot \mathrm{L}^{-1}$; $\left.\mathrm{p} \leq 0.01\right)$.

\section{Factor of accumulation}

Values (median $\pm 68 \%$ confidence range) of the factors of accumulation determined at 2.5, 5 and $12 \mathrm{~h}$ after ciprofloxacin and 2.5, 5 and $24 \mathrm{~h}$ after sparfloxacin administration are depicted in table 1.

Sparfloxacin achieved significantly higher site to serum concentration ratios than ciprofloxacin for all three compartments (peak site to serum ratios of $11.0 \pm 4.3$, $65.5 \pm 28.4$ and $63.0 \pm 66$ vs $4.94 \pm 0.64,10.6 \pm 3.7$ and $10.6 \pm$ 3.7 for PMNs, AMs and ELF, respectively) ( $\mathrm{p} \leq 0.01)$.

\section{Adverse events}

No adverse event or significant change of laboratory values was observed during the study.

\section{Discussion}

This study demonstrated that sparfloxacin achieved higher concentrations in AMs and ELF than ciprofloxacin. This may be of particular relevance in the treatment of community-acquired pneumonia.

$S$. pneumoniae is still the predominant bacterial pathogen causing community-acquired pneumonia [28, 29]. Recently pneumococci with a decreased susceptibility to penicillin have been isolated with increasing frequency in many parts of the world, including Europe and the United States [30, 31]. Pneumococcal infections caused by penicillin intermediate and resistant strains have been shown to respond to high doses of intravenous penicillins and cephalosporins [32], but oral $\beta$-lactams are probably not sufficiently effective even for the treatment of penicillin intermediate isolates [33]. It has also been shown that penicillin-resistant pneumococci are often cross-resistant to many other antibiotics, such as macrolides, tetracyclines and co-trimoxazole [30, 34].

Therefore, fluoroquinolones have been considered as possible alternatives for the management of communityacquired pneumonia, because these agents possess a broad-spectrum in vitro activity, favourable pharmacokinetics, and exhibit high tissue distribution and effective penetration into extracellular fluids. Widely-used fluoroquinolones, such as ciprofloxacin and ofloxacin, have excellent activity against Gram-negative pulmonary pathogens, but they have only marginal activity against $S$. pneumoniae with the minimal concentration required to produce $90 \%$ inhibition (MIC90s) ranging 1-4 $\mathrm{mg} \cdot \mathrm{L}^{-1}$ compared to MIC90s of $<0.5 \mathrm{mg} \cdot \mathrm{L}^{-1}$ for most of the Gram-negative pathogens $[1,2,6]$. Clinical studies have shown ciprofloxacin and ofloxacin to have good clinical efficacy in the treatment of bronchopulmonary infections due to $S$. pneumoniae [35], but other investigators have reported low clinical success rates with a high rate of persistence of $S$. pneumoniae after therapy [36]. In addition, failures of pneumococcal pneumonia with breakthrough bacteraemia have been recorded [37].

The superior in vivo activity [38-40] of sparfloxacin is partly due to the higher intrinsic activity against these organisms in vitro [41] compared to that of other quinolones, but the pharmacokinetic properties seem to be of importance as well. We were able to demonstrate that after administration of a single oral dose, sparfloxacin $400 \mathrm{mg}$ achieved considerably higher concentrations in the alveolar compartment of the lung compared to ciprofloxacin $500 \mathrm{mg}$. By using the BAL methodology it is possible to investigate the distribution of antimicrobial agents in two different potential sites of pulmonary infection, ELF and AMs. The present results indicate that concentrations of sparfloxacin in both compartments greatly exceeded those of ciprofloxacin. We must bear in mind that the factors of accumulation for sparfloxacin were artificially higher because of the low serum levels; however, the concentrations of sparfloxacin at tissue sites were also higher than the concentrations of ciprofloxacin in absolute terms.

ELF is considered to be an important site where pneumococcal pneumonia may develop. Sparfloxacin achieved concentrations in ELF that exceeded the minimum inhibitory concentrations (MICs) of S. pneumoniae (MIC90 0.25-0.5 $\mathrm{mg} \cdot \mathrm{L}^{-1}$ ) during the whole recommended $24 \mathrm{~h}$ dosing interval by more than 40 times. In contrast, ciprofloxacin displayed relatively low penetration into the ELF.

AMs and PMNs both represent potential sites for intracellular infection. Compared to ciprofloxacin, sparfloxacin attained concentrations five times higher in AMs. The concentrations of sparfloxacin greatly exceeded the MICs of common intracellular pathogens, such as Chlamydia pneumoniae $[8,9]$. Both quinolones achieved similar concentrations in PMNs, but ciprofloxacin was more rapidly released from the neutrophils than sparfloxacin.

The results of the serum concentration-time curves and the elimination half-lives of both quinolones are in accordance with data published previously [12-14, 4244]. These investigators studied the penetration of several fluoroquinolones into AMs and ELF and bronchial mucosa, and found a better penetration by sparfloxacin compared to ciprofloxacin, lomefloxacin, temafloxacin and rufloxacin. In vitro studies demonstrated that the accumulation ratio of sparfloxacin in $\mathrm{J} 774$ macrophages and in infected and noninfected tissue culture cells was significantly higher than that obtained for other quinolones [45]. Wise and HonEybouRne [46] proposed that the better penetration of sparfloxacin into pulmonary tissues and fluids might be related to the physicochemical properties rather than the pharmacokinetic properties of this compound. Theoretically, the higher hydrophobicity of sparfloxacin facilitates the penetration through cell membranes, but the exact mechanisms involved have yet to be determined.

Excellent in vitro activity, improved pharmacokinetic properties, the possibility of single daily dosing and 
the increased half-life of sparfloxacin as compared with the fluoroquinolones available at present makes it a suitable candidate for the treatment of lower respiratory tract infections [1, 47, 48]. However, the indication for treatment with sparfloxacin will have to be decided with care, because of some toxicological problems, such as photosensivity and Qtc interval prolongation [49]. Our results confirm the approach of investigating the different pharmacokinetic characteristics of new antibiotics in the "lung compartment", before recommending rational dosages in lower respiratory tract infections.

\section{References}

1. Canton A, Pemán J, Jiminez MT, Ramón MS, Gobernado M. In vitro activity of sparfloxacin compared with those of five other quinolones. Antimicrob Agents Chemother 1992; 36: 558-565.

2. Cooper MA, Andrews JM, Ashby JP, Matthews RS, Wise $\mathrm{R}$. In vitro activity of sparfloxacin, a new quinolone antimicrobial agent. J Antimicrob Chemother 1990; 26: 667-676.

3. Malmborg A-S, Ahlén S. In vitro activity of sparfloxacin compared with ciprofloxacin and ofloxacin against respiratory tract pathogens. Chemotherapy 1993; 39: $32-35$.

4. Simor AE, Fuller SA, Low DE. Comparative in vitro activities of sparfloxacin (CI-978; AT-4140) and other antimicrobial agents against staphylococci, enterococci, and respiratory tract pathogens. Antimicrob Agents Chemother 1990; 34: 2283-2286.

5. Spangler SK, Jacobs MR, Appelbaum PC. Susceptibilities of penicillin-susceptible and -resistant strains of Streptococcus pneumoniae to RP 59500, vancomycin, erythromycin, PD 131628, sparfloxacin, temafloxacin, WIN 57273, ofloxacin and ciprofloxacin. Antimicrob Agents Chemother 1992; 36: 856-859.

6. Focht J, Nösner K, Kresken M. Sensitivity of community- and hospital-acquired bacterial isolates to sparfloxacin in comparison with other antibiotics. Drugs 1993; 45 (Suppl. 3): 152-156.

7. Wexler HM, Molitoris E, Finegold SM. In vitro activities of three of the newer quinolones against anaerobic bacteria. Antimicrob Agents Chemother 1992; 36: 239-243.

8. Hammerschlag MR, Hyman CL, Roblin PM. In vitro activities of five quinolones against Chlamydia pneumoniae. Antimicrob Agents Chemother 1992; 36: 682-683.

9. Kenny GE, Cartwright FD. Susceptibility of Mycoplasma pneumoniae to several new quinolones, tetracycline and erythromycin. Antimicrob Agents Chemother 1991; 35: 587-589.

10. Nakamura S, Minami A, Nakata $\mathrm{K}$, et al. In vitro and in vivo antibacterial activities of AT-4140, a new broad spectrum quinolone. Antimicrob Agents Chemother 1989; 33: $1167-1173$.

11. Honeybourne D, Greaves I, Baldwin DR, Andrews JM, Harris M, Wise R. The concentration of sparfloxacin in lung tissues after single and multiple oral doses. Int $J$ Antimicrob Agents 1994; 4: 151-155.

12. Johnson, JH, Cooper MA, Andrews JM, Wise R. Pharmacokinetics and inflammatory fluid penetration of sparfloxacin. Antimicrob Agents Chemother 1992; 36: 2444-2446.

13. Shimada J, Nogita T, Ishibashi Y. Clinical pharmacokinetics of sparfloxacin. Clin Pharmacokinet 1993; 25: $358-369$.
14. Trautmann M, Ruhnke M, Borner K, Wagner J, Koeppe P. Pharmacokinetics of sparfloxacin and serum bactericidal activity against pneumococci. Antimicrob Agents Chemother 1996; 40: 776-779.

15. Baldwin DR, Honeybourne D, Wise R. Pulmonary disposition of antimicrobial agents: methodological considerations. Antimicrob Agents Chemother 1992; 36: $1171-1175$

16. Tulkens MP. Intracellular pharmacokinetics and localisation of antibiotics and their efficacy against intracellular infections. Scand J Infect Dis 1991; 74: 209-217.

17. Reynolds HY. Bronchoalveolar lavage. In: Murray JF, Nadel JA, eds. Textbook of Respiratory Medicine. New York, W.B. Saunders Co., 1988; pp. 597-610.

18. Schaberg T, Haller H, Rau M, Kaiser D, Fassbender M, Lode H. Superoxide anion release induced by plateletactivating factor is increased in human alveolar macrophages from smokers. Eur Respir J 1992; 5: 387-393.

19. Boyum A. Isolation of mononuclear cells and granulocytes from human blood. Scand J Clin Lab Invest 1968; 21 (Suppl. 97): 77-89.

20. Reeves DS, Bywater MJ. Assay of antimicrobial agents. In: de Louvois, ed. Selected Topics in Clinical Bacteriology. London, Bailliere Tyndall, 1976; pp. 21-55.

21. Theodore WM, Merill WW, Rankin JA, Reynolds HY. Limitations of using urea to quantify epithelial lining fluid recovered by bronchoalveolar lavage. Am Rev Respir Dis 1987; 135: 1276-1280.

22. Rennard SI, Basset G, Lecossier D, et al. Estimation of volume of epithelial lining fluid recovered by lavage using urea as marker of dilution. J Appl Physiol 1986; 60: 532-538.

23. Maderazo EG, Breaux SP, Woronick CL, Quantiliani $\mathrm{R}$, Nightingale $\mathrm{CH}$. High teicoplanin uptake by human neutrophils. Chemotherapy 1988; 34: 248-255.

24. Schwarz G. Estimating the dimension of a model. Ann Statistics 1978; 6: 461-464.

25. Koeppe P, Hamann C. A program for nonlinear regression analysis to be used on desk-top computers. Comput Progr Biomed 1980; 12: 121-128.

26. Peck CC, Sheiner LB, Nicols AI. The problem of choosing weights in nonlinear analysis of pharmacokinetic data. Drug Metab Rev 1984; 15: 133-148.

27. Wilcoxon F, Wilcox RA. In: Some Rapid Approximate Statistical Procedures. Lederle Laboratoires, Pearl River, New York 1964; pp. 13-27.

28. Örtqvist A, Hedlund J, Grillner L, et al. Aetiology, outcome and prognostic factors in community-acquired pneumonia requiring hospitalization. Eur Respir J 1990; 3: $1105-1113$.

29. Fang G-D, Fine M, Orloff J, et al. New and emerging etiologies for community-acquired pneumonia with implications for therapy: a prospective multicenter study of 359 cases. Medicine 1990; 69: 307-316.

30. Doern GV, Brueggemann A, Holley HP Jr, Rauch AM. Antimicrobial resistance of Streptococcus pneumoniae recovered from out-patients in the United States during the winter months of 1994 to 1995: results of a 30 center national surveillance study. Antimicrob Agents Chemother 1996; 40: 1208-1213.

31. Baquero F. Pneumococcal resistance to $\beta$-lactam antibiotics: a global geographic overview. Microb Drug Res 1995; 1: 115-120.

32. Jacobs RF, Kaplan SL, Schutze GE, et al. Relationship of MlCs to efficacy of cetotaxime in treatment of Streptococcus pneumoniae infections. Antimicrob Agents Chemother 1996; 40: 895-898. 
33. Barry B, Gehanno P, Blumen M, Boucot I. Clinical outcome of acute otitis media caused by pneumococci with decreased susceptibility to penicillin. Scand J Infect Dis 1994; 26: 446-452.

34. Reinert RR, Queck A, Kaufhold A, Kresken M, Lütticken R. Antimicrobial resistance and type distribution of Streptococcus pneumoniae isolates causing systemic infections in Germany. Clin Infect Dis 1995; 21: 398-401.

35. Thys JP, Jacobs F, Byl B. Role of quinolones in the treatment of bronchopulmonary infections, particularly pneumococcal and community-acquired pneumonia. Eur J Clin Microb Infect Dis 1991; 10: 304-315.

36. Davies BI, Maesen FPV, Baur C. Ciprofloxacin in the treatment of acute exacerbation of chronic bronchitis. Eur J Clin Microb Infect Dis 1986; 5: 226-231.

37. Cooper B, Lawlor M. Pneumococcal bacteremia during ciprofloxacin therapy for pneumococcal pneumonia. Am J Med 1989; 87: 475-478.

38. Azoulay-Dupuis E, Vallee E, Veber B, Bedos JP, Bauchet $\mathrm{J}$, Pocidalo J-J. In vivo efficacy of a new fluoroquinolone, sparfloxacin, against penicillin-susceptible and resistant and multiresistant strains of Streptococcus pneumoniae in a mouse model of pneumonia. Antimicrob Agents Chemother 1992; 36: 2698-2703.

39. Nakata K, Okazaki Y, Hattori H, Nakamura S. Protective effects of sparfloxacin in experimental pneumonia caused by Chlamydia pneumoniae in leukopenic mice. Antimicrob Agents Chemother 1994; 38: 1757-1762.

40. Nakata K, Maeda H, Fuji A, Arakawa S, Umezu K, Kamidono S. In vitro and in vivo activities of sparfloxacin, other quinolones and tetracyclines against Chlamydia trachomatis. Antimicrob Agents Chemother 1992; 36: 188-190.

41. Wiedemann B, Kratz B, Steines A. Comparative study on the pharmacodynamic activity of sparfloxacin and ciprofloxacin in an in vitro model with S. pneumoniae. 7th European Congress of Clinical Microbiology and Infectious Diseases, Vienna, 1993; Abstract No. 714.

42. Wise R, Honeybourne D. Antibiotic penetration into the respiratory tract: a basis for rational therapy. Chemotherapy 1995; 4: 28-32.

43. Kucers A, Bennet MMcK. The Use of Antibiotics: Ciprofloxacin. 4th Edn. London, William Heinemann Medical Books, 1987; pp. 1248-1263.

44. Vance BK, Guay DR, Rotschafer JC. Clinical pharmacokinetics of ciprofloxacin. Clin Pharmacokinet 1990; 19: 434-461.

45. Garcia I, Pascual A, Guzman MC, Perea EJ. Uptake and intracellular activity of sparfloxacin in human polymorphonuclear leucocytes and tissue culture cells. Antimicrob Agents Chemother 1992; 36: 1053-1056.

46. Wise R, Honeybourne D. A review of the penetration of sparfloxacin into the lower respiratory tract and sinuses. J Antimicrob Chemother 1996; 37 (Suppl. A): 5763.

47. Miyamoto R, Matsumoto J, Chiba K, et al. Synthesis and structure activity relationships of 5 substituted 6,8difluoroquinolones, including sparfloxacin, a new quinolone antibacterial agent with improved potency. $\mathrm{J} \mathrm{Med}$ Chem 1990; 33: 1645-1656.

48. Lode H, Garau J, Grassi C, Hosie J, et al. Treatment of community-acquired pneumonia: a randomized comparison of sparfloxacin, amoxycillin-clavulanic acid and erythromycin. Eur Respir J 1995; 8: 1999-2007.

49. Lipsky BA, Dorr MB, Magner DJ, Talbot GH. Safety profile of sparfloxacin in North American phase III clinical trials. 36th ICAAC, New Orleans, Louisiana, 1996; No. L013. 